\title{
The Water Act, No. 54 of 1956 and the first phase of apartheid in South Africa (1948-1960)
}

\author{
Johann Tempelhoff ${ }^{1}$
}

Received: 23 January 2016/Accepted: 9 September 2016/Published online: 1 February 2017

(C) The Author(s) 2017. This article is published with open access at Springerlink.com

\begin{abstract}
After the formation of the Union of South Africa in 1910 the government department responsible for water governance, in terms of the Irrigation and Conservation of Water Act, No. 8 of 1912 went by the name of the Department of Irrigation. In 1956, when the Water Act, No. 54 of 1956, was passed its name changed to the Department of Water Affairs. The new legislation marked the beginning of a new era in South Africa's water governance. The focus of the department shifted from irrigation infrastructure and bulk water governance responsibilities, to make an important contribution to the country's social and economic development. Priorities of the day included the need for more comprehensive water infrastructure for industrial development; the greater demand for water in the country's rapidly growing urban areas; and taking steps against the increasing threat of water pollution. In this paper the focus is on the way the department, in terms of the Water Act of 1956, responded to the policy of separate development (apartheid), but at the same time took a deeper and long-term view of the development of water infrastructure to be of value for the country and its people, beyond the shorter temporal view of the political leaders of the day. The period 1948-1960 can be seen as the first phase of apartheid (1948-1960). It was notable for the initial emergence of significant opposition amongst the country's indigenous African people to the white minority government's apartheid policies, but their struggle was subdued. This phase came to an end at a time when the rest of Africa was engaged in rapid decolonisation and South Africa became politically ostracised in the international arena. What is apparent is that the emergent hydraulic mission of industrialisation promoted unsurpassed development that was destined to have a marked effect on South Africa's status as a modern state on the African continent.
\end{abstract}

Johann Tempelhoff

johann.tempelhoff@nwu.ac.za

1 Subject Group History, School of Basic Sciences, North-West University, Vaal Triangle Campus, Vanderbijlpark, Gauteng 1900, South Africa 
Keywords Water Act No. 54 of 1956 - Apartheid · Water governance - South Africa · Urbanisation · Homelands · Bantustans · Irrigation · Urban water and sanitation · Industrial development

\section{Introduction}

A notable feature of South Africa's water legislation has been its consistency. In the course of the 20th century only four primary pieces of legislation related to water governance were passed by parliament. Each of the four pieces of legislation laid down a primary definition of how the water resources of the country would be developed. At the same time each was representative of a ground breaking shift in the way the state was governed. For example, the Irrigation and Conservation of Water Act, No. 8 of 1912 (Union of South Africa (U of SA) 1912; Murray 1952, pp. 283-482), came into effect in the aftermath of the formation of the Union of South Africa in 1910 — when the four former British colonies of the Cape of Good Hope, Natal, Transvaal and the Free State united to form a unitary state. The Transvaal and Free State, for the greater part of the 19th century, had been frontier republics, and after the South African War (1899-1902) significant political manoeuvring and a preliminary piece of colonial legislation, the Cape Irrigation Act 32 of 1906, was necessary to prepare the way for effective water governance after the formation of the Union of South Africa (Hall and Burger 1974, p. 6). The Irrigation Act of 1912 therefore contributed to an enabling environment of appeasement, one specifically attuned to development. In a predominantly farming society the objective was to ensure there was sufficient water for the agricultural sector in meeting the country's demand for food. Another priority was to construct water storage facilities and giving attention to the conservation of water resources. The Irrigation Department was clearly dedicated to an agricultural hydraulic mission.

More than 40 years later, when the legislature promulgated the Water Act, No. 54 of 1956 (U of SA 1956), the first objective was to consolidate and amend South Africa's existing legislation related to the control, conservation and use of water. But the primary long-term objective was to ensure that there were sufficient water supplies to support South Africa's growing social, economic and industrial development - with the mining industry a key beneficiary. Accordingly, the industrial hydraulic mission was focused on meeting the needs of rapid urbanisation and regional development in catchment areas; it had to deliver the available water resources to areas where it could be used most effectively. Significantly, the new water legislation was passed in 1956, eight years after the National Party came to power, and its introduction coincided with the new government's policy of separate development (apartheid) - a policy that was underpinned by racial discrimination against people of colour. Apartheid permeated all sectors of political, social and economic life in South Africa in the period 1948 to 1990. By 1960, as a result of its apartheid policy, increasing oppression and the banning of the liberation movements, South Africa became a pariah state in the eyes of the international community. Subsequently the Water Act has been interpreted in a variety of ways ranging from typically 'colonialist' to being 'fair and beneficial' (Tewari 2009; Wall 2011, p. 271).

The most recently introduced legislative measures are the Water Services Act, No. 109 of 1997 (Republic of South Africa (RSA) 1997), and the National Water Act, No. 39 of 1998 (RSA 1998). Both were passed after South Africa's transition in 1994 to a multiracial 
democracy (Department of Water Affairs and Forestry (DWAF) 2006). The content and intent of the new acts were significantly different from all previous water legislation in that the prime principles were now equity for all water users and the need for the government to act as custodian of the resources on behalf of all the country's people. The result was the emergence of a clearly defined social hydraulic mission. At a deeper level and over the longer term the new water legislation introduced the basic principle of balancing resource use with the counterpoint of resource protection. There were also preliminary indications of a move towards sustainable development but not in itself a sustainable practice.

\section{Outline}

For the purposes of this discussion the focus is on the early phase of the apartheid era (1948-1960) and to determine how the policy influenced the implementation of the country's 1956 water legislation. The periodisation is based on the scholarship of Harold Wolpe (1990) published at the time when the rule of the National Party was drawing to a close. For Wolpe, the apartheid era unfolded in three phases. The first, from 1948 to 1960 , was notable for the decline in the structural conditions of mass struggle. The second (1960-1972) saw state repression gathering momentum in an attempt to 'put down' the armed struggle. The third phase, as of 1973, Wolpe describes as a time of insurrection, coinciding with a liberation struggle that increasingly forced the apartheid state into defence mode - and led to its ultimate demise.

Apart from the works by Uys (1994), Turton et al. (2004), Tewari (2009), and Van Vuuren (2009), that provide comprehensive views of the evolution of South Africa's water governance, there has not been much focus, since 1994, on a historical assessment of the Water Act of 1956. Departmental officials, legal experts and consulting specialists such as Hall and Burger (1974), Conley (DWA, 1988), Triebel and Van Niekerk (1994) and Thompson (2006) have provided valuable and interesting perspectives. However, a critical factor, the development of apartheid in the 1950s, is often neglected. By focusing in this discussion on 1948-1960, with limited forays into the periods before and after this date span, the objective is to consider: (i) How planning by government and senior officials in the country's water sector in the 1930s paved the way for more relevant water legislation for South Africa, legislation which stimulated a '1950s syndrome' that later manifested in many parts of the world as unsustainable development. (ii) The way the National Party government, from 1948 onwards, embraced the planning of new water legislation. (iii) The stipulations of the Water Act 54 of 1956; and (iv) how the policy of apartheid influenced the livelihoods of disadvantaged South Africans living in the rural and urban areas respectively. The legislation was clearly loaded with hydropolitical objectives that became evident by the 1960 s.

On 21 March 1960 at Sharpeville, near Vereeniging, a protest against the pass system reached breaking point and police opening fire killing unarmed protesters. Soon South Africa was isolated in world politics-just at a time when the decolonisation of Africa gained momentum. The final part of the discussion is an assessment, partly of exogenous factors, that shaped the way the Water Act was implemented to serve certain objectives of the apartheid policy.

What does become evident, not only in South Africa, but wherever there are indications of innovations in state formation or political transformation, is that an ubiquitous hidden power of water is at play (Fagan 2011; Solomon 2010; Fishman 2011). In South Africa's 
water history, legislation and amendments tended to dovetail neatly with many ideologically-inclined policy objectives cherished by the government of the day. However, such objectives are usually of a relatively short duration and are subject to change, especially in a democratic dispensation where successive governments build forth on policy priorities which the electorate supports. At the same time, in the case of the water sector, there is evidence of long-term priorities which played an influential role in the planning of new legislation. In the case of South Africa this type of thinking has a direct bearing on the way scarce water resources, so vital for every aspect of development, need to be managed for the greater benefit of the country and its people. As a rule, long-term thinking is the responsibility of the state's water sector, with senior officials and their technical advisors assessing the viable objectives and relevant legal measures. It is here that the hidden power of water manifests itself. There is also evidence of water invisibly at play in the consumer sector in the period under consideration. This will become evident as the discussion unfolds.

\section{Water sector development and the '1950s syndrome' (1939-1955)}

South Africa's first national water legislation, the Irrigation and Conservation of Water Act, No. 8 of 1912, marked the consolidation and codification of the most relevant existing water-related legislation of the former colonies of the Cape of Good Hope, Natal, the Free State and Transvaal that became part of the Union of South Africa in 1910. ${ }^{1}$ The 1912 legislation focused ostensibly on: the development of irrigation (Anon 1987, p. 39); riparian water rights (Triebel and Van Niekerk 1994, p. 35); and matters related to the conservation (storage) of resources before this inherently valuable water flowed out into the sea. Although many smaller, water-related measures were passed into law in the period before 1956, they were subsidiary to the legislation that governed the activities and focus of the Irrigation Department, as it was known until 1956 (Murray 1952, pp. 273-281). The need for changing the legislation was largely because of developmental changes that had transpired since 1910. By the 1930s industrial development, particularly in the mining sector, gave the South African economy sufficient thrust to sidestep the worldwide economic depression. The country became less dependent on exporting farming produce (Freund 2011 p. 221; Seekings 2016, pp. 193-196).

Posel singles out the 'desire' of the apartheid-era rulers to shape South Africa into a powerful state (Posel 2011, p. 330). Contemplated from the perspective of South Africa's water sector, it is evident that the idea had its origins well before 1948. As early as the mid1930s there was already talk among politicians and senior water sector officials of replacing the Irrigation Act of 1912. The amendments made to the existing legislation had proved only partially effective, but it seems there was no apparent political agenda pushing for change. Departmental officials were more than aware of the mentality of the farming community. Indeed, there were claims, in some cases justified, that many farmers assumed they had a privileged right of access to water (Horak 1978, p. 330). This was in part a result of the dedicated attention given by the department in the development of water storage facilities and irrigation schemes. A number of large irrigation schemes began operations in the 1930s. Most were costly and seldom operated at a profit. The trend was most evident in the government irrigation schemes such as Hartbeespoort (1915-1925), Vaalharts

\footnotetext{
1 Neither the Free State nor Natal had formally promulgated water-related legislation. They continued to apply common law until the promulgation of the Irrigation Act in 1912.
} 
(1933-1938), Loskop (1934-1938), Rust der Winter (1931-1934), Marico (1930-1935) and Pongola (1931-1934). The Irrigation Commission, a think tank that advised government and reported to parliament on water matters, recommended an 'ease down' on further irrigation expansion. The commission, as well as officials of the Irrigation Department were of the view that the schemes would take a considerable period of time before they reached mature productive capacity (U of SA UG4/1938, pp. 5-6). Meanwhile industrial development, especially in the field of mining, was making rapid strides forward.

A more progressive South African approach to water governance, typically part and parcel of the idea of the emergent big state in a globalising world (Solomon 2010, Chapt. 13), had its origins in the era of World War 2 when in the early 1940s the United Party government under JC Smuts, began comprehensive development planning for the future South Africa. Conley suggests that the first pointer of change was the development in 1943 of a regional water supply scheme-essentially a wartime project for defence purposes at the South African Navy's port of Saldanha Bay (Conley 1988, p. 223). Even before its completion the project, developed in collaboration with the military authorities, had all the makings of a scheme aimed at water supply for local industries, the operations of the South African Railways and local urban communities in the region (Visser et al. 2008).

At the time a number of well-informed specialists in the fields of social economic planning, regional planning and industrial development, such as HJ van Eck, TJD Fair, and $\mathrm{HJ}$ van der Bijl, were among the experts who advised the government in its drive to become directly involved in social and economic development. Of particular importance were town and regional planning projects, and there was also a concerted drive to support mining and related industrial development. New institutions that emerged, included the Social and Economic Planning Council (1942); the Industrial Development Corporation (1943); and the Natural Resources Development Council in 1947 (Anon 1942 pp. 231-233; Mabin and Smit 1997, pp. 204-205; Parnell and Mabin 1995, pp. 55-56; Union of South Africa (U of SA), 1947). The latter, a highly influential institution, had its origins early in 1947 in an advisory committee on development in the Orange Free State. As a result of the council's subsequent work in the area, government gave the nod for the development of the Free State goldfields. Needless to say, the project required water resources from the Vaal River. Up to 1945 irrigation farmers of the Vaalharts scheme and the mining industry on the Witwatersrand goldfields had the lions' share of the water in the Vaal River system. Now, by 1947, the supply had to be shared.

The major drivers of change after World War 2 were economic forces that in turn sparked off a number of management needs. For example, LA Mackenzie, Director of the Irrigation Department in 1947 bought into the project, but with the proviso that:

In a country ... whose major obstacle to expansion is so obviously water, it follows that ... development must be planned (Union of South Africa (U of SA), Mackenzie, LA 1947, p. 2).

He wrote extensively on South Africa's water resources and matters related to irrigation. Consequently, prior to his retirement with superannuation in 1952, he was hard at work planning the future legislation of South Africa (Anon 1987, p. 41).

In 1946-1947 the government water think tank, the Irrigation Commission, conducted an investigation in South Africa and also visited Australia to find out how that country's farming sector operated in the field of irrigation. In an extensive report, the commission recommended that the existing policy had to be revised (Union of South Africa (U of SA), UG40/1953). Mackenzie, articulating management thinking, explained that the Irrigation Act had focused primarily on the agricultural use of water, both in the domestic and 
irrigation sector. It no longer met ever-increasing needs in the mining, urban and industrial sectors. He explained:

... the time is ripe for a complete revision of the Act to meet the present changed circumstances (Union of South Africa (U of SA), UG55/1947, p. 11).

In 1951, JP Leslie, chief engineer of the Rand Water Board and president of the South African Institute of Civil Engineers (SAICE), sensing bulk water shortages, warned against potential water privatisation:

[T] he principles embodied in our legislation controlling the use of water provide only for the development of agriculture and throw the onus for providing essential water for urban and industrial use so much on the individual as to compel him to seek the friendly aid of undertakings, who by expensive legislation and conservation have secured some rights to water. These difficulties can only lead to haphazard planning and waste (Leslie 1951, p. 27).

Water sector managers were aware that the country's water resources were increasingly under duress and in danger of becoming finite. The traditional surplus storage facilities (an array of dams built between 1915 and the late 1930s) no longer secured all the water the country needed. Mackenzie argued that mineral resources in the aftermath of World War 2 had created development opportunities that exceeded all expectations and deserved to be supported (Union of South Africa (U of SA), UG55/1947, p. 11). Given the fact that mining and industrial development since the 1930s had made a significantly larger contribution to the economy of South Africa than ever before, there was, after 1945, a need to shift from the department's agricultural hydraulic mission ensconced in the 1912 legislation. An industrial hydraulic mission was the next logical step.

\section{The role of the National Party in implementing the Water Act (1948-1955)}

After World War 2, an important talking point in international political circles was the approaching advent of European decolonisation in Africa, South America and Asia. Many colonial powers began to revise their colonial policies in Africa. In parts of the continent, like South Africa, the imminent transition was met with indifference, largely because of the relatively large population of people of European descent who had been resident in southern Africa for more than three centuries. For example, although South Africa's existing water legislation reeked of 'colonialism' (Tewari 2009, p. 695) it did not significantly influence the government of the day to make amends. Government's standpoint was largely as a result of the surprise victory of the National Party in the May 1948 parliamentary elections. The party's thinking was more conservative than the ousted United Party government and the National Party had a staunch Afrikaner nationalist support base. For all intents and purposes, therefore, legal discrimination against people of colour remained intact with the advent of the new government. Indeed, in some respects, government became even more discriminatory. The best examples were the existing Land Act, No. 27 of 1913, which divided land between blacks and whites; the Natives Trust and Land Act, No. 18 of 1936, that prevented Africans from freehold ownership of land of their choice; and the new (and particularly notorious) Group Areas Act, No. 41 of 1950, that made residential separation compulsory between racial groups. It also controlled Africans' 
right of access to 'white' areas, and by implication, also to proper water supply and sanitation (Tewari 2009, p. 702).

Prime Minister DF Malan appointed JG Strijdom (1893-1958) as Minister of Water Affairs. A dyed-in-the-wool Afrikaner nationalist, Strijdom was also a passionate farmer who in his maiden speech in parliament way back in 1929, spoke on the topic of water conservation and irrigation (Van Rensburg 1977, pp. 785-793). He subsequently did much to promote the cause of farming in the northern parts of South Africa long before the National Party's 1948 victory (Basson 1980, pp. 599-600). He also kept a clear focus on the objectives and the need for responsible water management and facilitated the government decision on 17 April 1950 to appoint a commission of inquiry into water legislation (Anon 1987, p. 41).

The commission, under the chairmanship of Justice CG Hall, an expert on the evolution and development of South African water law (Hall 1939, 1947), reported in 1952 on its findings. The proposed new water bill was first submitted to parliament during the 1954 session-shortly before Strijdom succeeded Malan as prime minister. Subsequently PO (Paul) Sauer, another Afrikaner nationalist of note, became the new Minister of Lands and Irrigation (Scholtz 1987). The new water legislation did not have an easy ride through parliament as a result of its complexity. After the first reading it was referred to a select committee, but the committee's work could not be completed in the 1954 session. Eventually, on 25 February 1955, the House of Assembly scheduled a discussion of the water bill for the 1955 session. Dr Albert Hertzog, son of a former premier and influential leader in the National Party government, chaired the select committee dealing with the matter. The Hertzog Committee resumed deliberations in February 1955 and by 31 March 1955 there had been no less than 13 meetings to discuss the bill (Union of South Africa (U of SA) UG24/1956, p. 7), which finally paved the way for the approval of the Water Act, No. 54 on 12 June 1956 (Union of South Africa (U of SA), Water Act, No. 54 of 1956; Anon 1987, p. 41).

After the approval of the Water Act, government had its work cut out. Ever since Union in 1910 the irrigation farming sector, primarily led by farmers in in the Cape Province, had been an influential force in the country's politics. They gained a dubious reputation for undermining the work of water officials if new departmental innovations and strategies were not to their liking (Kanthack 1924 p. 178; Mackenzie 1947, p. 12). Added to this, a significant portion of the National Party's support base was in the farming sector and government tended to carry the interests of its constituency close to its heart. But at the same time, officialdom promoted plans for industrial development (Davies et al. 1976, p. 27). Those involved in water governance stressed that the country's economic wellbeing required the release of substantial supplies of water for diverse purposes. They pointed out that the privileged status of agriculture as the prime beneficiary of the well-managed water supplies had to be reconsidered. There was a need to make provision for mining, manufacturing and commercial development in the burgeoning metropolitan areas of South Africa. A microcosm of the future water conundrum was the Vaal River catchment system on which the Council for Natural Resources brought out an influential report in 1953. The report pinpointed the need for long-term planning on water resources in the PretoriaWitwatersrand-Vereeniging region where $30 \%$ of the country's population resided (Union of South Africa (U of SA), UG40/1953). The region was the heartland of the country's financial institutions and industrial concerns. Undeniably, water was key to future development.

To all intents and purposes the government (as was the case in most Western economies at the time) was caught up in what economists and environmental historians have labelled 
as the '1950s syndrome' - a phase of economic development characterised by rapid progress which was destined to shape global unsustainability later in the 20th century (Pfister 2010, Locs 1250-1597). For example, from the late 1940s the predominantly rural Orange Free State Province was on the cusp of a mining boom. The Vaal River Development Scheme Amendment Act, No. 21 of 1948, made provision for the water of the Vaal River to be used extensively for purposes other than mere irrigation and one of the prime foci was on the province's new goldfields (Union of South Africa (U of SA), UG65/1949, p. 7). Gold mining activities and the new town of Welkom required substantial supplies of water for domestic and industrial consumption, regardless of the higher rates proposed by the newly named Department of Water Affairs (SAWHAR, WAC 1955).

There were also calls for more water to be made available in the new Free State urban centre of Sasolburg, founded in 1950. The town is conveniently situated on the banks of the Vaal River not far from the coalfields of the northern Free State. Sasolburg was to become the home of the water-intensive industry of SASOL, South Africa's petroleum from coal manufacturing industry (Meintjes 1975, pp. 12-48). At the same time the parastatal Electricity Supply Commission (Escom) extended its services to many parts of the country and more coalfields were opened to support a growing number of thermal power stations on the Eastern Transvaal Highveld (Van Vuuren 2012, pp. 185-191; Singer 2011, pp. 44-45, 63-64). In addition by 1955, in the Transvaal Lowveld at Phalaborwa, a comprehensive parastatal mining project was under way for the production of phosphates. This new mining initiative relied on the nearby Olifants River for its water supplies (Turton et al. 2004, p. 73). Water resources also featured prominently in the plans for developing other parts of the Lowveld (Fair and Webb 1954), ${ }^{2}$ as well as the province of Natal where comprehensive regional planning projects had been under way for some time (Mabin, 1992, p. 414). It is evident that well before the passing of the Water Act there had been comprehensive sectoral consultation and probably some measure of potential acceptance for the implementation of these initiatives. If apartheid featured in these plans it must have been an offshoot of the industrialisation project devised by the government in consultation with the private sector.

\section{The Water Act, 54 of 1956}

The Water Act of 1956 focused on the need for effective water governance. Its stated aim was to "consolidate and amend the laws in force in the Union relating to the control, conservation and use of water for domestic, agricultural and industrial purposes' (Union of South Africa (U of SA), Water Act, No. 54 of 1956, Sec. [S]1). Through the responsible minister and the senior state-appointed official, the Secretary of the new Department of Water Affairs, the government intended taking firm control over water supplies, including private and public water (S2-3). Local authorities were entitled to take water within their specific municipal areas for urban consumption purposes (S4-8 and 9). Furthermore, the state took control of subterranean water and water found underground (S27-33). The system of water courts, originally outlined in the Irrigation

\footnotetext{
2 TJD Fair and HW Webb, "The South-Eastern Transvaal Lowveld: A Survey of the Resources and Development of the Southern Lowveld Region of the Eastern Transvaal," Barberton: Lowveld Regional Development Association (1954). (Cape Times Limited, Parow 1954).
} 
Act of 1912, was maintained, but with greater responsibilities resting with the water authorities. It was the water courts that had to decide on legal matters relating to government water control areas in the various provinces and sub-divisions of provinces, specifically with a view to accommodating well-defined catchment areas (Hall and Burger 1974, pp. 123-124). In addition, the 1956 Act accorded the state the right to embark on the construction and control of government water works (S56-70), including the construction of dams, irrigation schemes, and the generation of electricity (S67). The duties and responsibilities of irrigation boards and water boards were meticulously outlined, to ensure more effective governance in both agricultural and non-agricultural user sectors. The introduction of formal subsidies was a firm commitment by government to make a contribution to the development of wastewater treatment works and water purification plants in the country's urban areas.

There are a few discernible signs of promoting the policy of apartheid in the first published version of the Water Act. What could perhaps be interpreted as a pointer to future apartheid planning appears in Chap. 10, where Sec. 176 makes reference to the 'native areas' (territories earmarked for the future development of homelands). The reader is informed that these areas would not be subject to the stipulations mentioned in Chap.s 3, 4, 7 and 9, clauses that respectively had a bearing on the control of subterranean water; water courts; water boards; and irrigation loans, liabilities and subsidies (S176). Interestingly, the first amendment to the Water Act followed within a year of its initial approval. Amendment Act, No. 75 of 1957 stipulated that government had the right to expropriate land if and when it was for the purposes of establishing government-controlled water works (Hall and Burger 1974, pp. 8-10, 165-167). This meant that all land, even land in the socalled 'native areas', could be expropriated for the development of government water works.

For departmental officials the Water Act, No. 54 of 1956 revolved essentially around five key areas (Triebel and Van Niekerk 1994, p. 35). Firstly, the state took responsibility for the supply of large amounts of water for both irrigation and other purposes. The state was also given the task of making available comprehensive funding for the development and implementation of such schemes (Union of South Africa (U of SA), 1956, Sec. 56(3) and 63). Secondly, in terms of governance, the state took the responsibility for the administration of a water permit system. In the case of industrial and urban water users the government controlled the way bulk supplies of water were distributed to stakeholders. By implication the Water Act also worked in the public interest by taking responsibility for water quality and combating pollution in urban areas (Union of South Africa (U of SA) 1956, Sec. 12 and 13; Thompson 2006, pp. 107-109). Thirdly, the new legislation gave the Minister of Water Affairs the right to declare any defined water control area a specified responsibility of the state. The state, through the Water Act, vested in the appropriate Minister a large measure of control of public water. It was the implementation of the principle of dominus fluminis-a departure from the the riparian-rights principle. ${ }^{3}$ However, certain safeguards and qualifications remained in place to protect the rights of (private) riparian users (Union of South Africa (U of SA), 1956, Sec. 62). Fourthly, beyond the specified government controlled areas the rights of riparian users remained in place. The only difference was that under the Water Act, riparian owners had to have a permit to extract water for storage in special, facilities. For this purpose, consumers required a

\footnotetext{
3 The principle of dominus fluminis in water governance was prevalent in the Cape Colony prior to the British annexation of 1806. Its reintroduction in 1956 was a measure to bring under control what were seen as excessive claims to water resources by riparian property owners.
} 
special permit (Union of South Africa (U of SA) 1956, Sec. 9B). Finally, the new legislation made provision for local control. In former times local control was with local water boards and especially the irrigation boards, but in terms of the 1956 legislation, this control was extended to urban and industrial users. The new water boards provided bulk water supplies mainly for urban and industrial purposes. A further stipulation was to extend the function of water boards to include regional sewage schemes. Irrigation boards and water boards were under the direct supervision of the state (Triebel and Van Niekerk 1994, p. 35).

The legislation made provision for circumstances of natural disaster. In the case of floods, private users could stake their claim to storing 'surplus water' for personal use (Thompson 2006, pp. 64-74). This measure was a form of 'compensation' for the appropriation of greater authority over available water resources. The growth of South Africa's mining sector and the expansion of the industry implied that there was a need to distribute water to a variety of consumers, some of whom were not in urban areas. Another reason given for the need to pass the Water Act of 1956 was that because of the high capital costs involved in increasing the scope of regional and multi-purpose water projects, the focus had to be on using the available storage facilities in the best interest of national development (Turton et al. 2004, p. 378). In this respect the emergent process of widespread industrial development in various regions of the country, as well as the hinterland of metropolitan centres, required more reliable and direct governance oversight with more storage facilities. Water managers also had to be aware of the need to ensure that the quality of water did not deteriorate to unacceptable levels. In terms of industrial water pollution, the Witwatersrand gold mines were a good indicator of the kind of problems the water authorities faced by the 1950s. Between 1911 and 1935 an imperial ton of rock crushed in the gold extraction process on the mines required between 200 and $300 \ell$ of water. By 1946 the consumption of a typical crusher had increased to as much as $700 \ell$ per ton (Leslie 1951, p. 18). However, it was not only the mining industry that required more water.

In many respects the National Party victory of 1948, in political terms, was similar to that of the former United Party government (1934-1948). Policies adopted by the new government favoured 'capitalist rationalization, including the securing of foreign capital, loans and technical know-how' (Legassick 1974, p. 10). Neo-marxist scholars have pointed to two dominant forms of capitalism in South Africa since the 1920s: imperial capital (primarily in the mining sector); and national capital (primarily farming and the industrial sector). In the 1940s, evidently as a result of government support for the development of the Free State goldfields (imperial capital) and the new National Party government that supported farming and industrial development (national capital), there was a signal change in the animosity and strong competition of former times (Davies et al. 1976, pp. 4-30). Providing water for industrial development had become a strong priority. In the near future this meant that the government had to take steps against the negative consequences of industrial waste and toxic mine water (Adler et al. 2007, pp. 33-41).

Seen against the backdrop of the apartheid policy there was considerable 'social engineering' at the heart of all aspects of governance in the country from 1948 onwards. The industrial hydraulic mission also had wide ranging social ramifications. The introduction of separate townships for people of different races in urban areas, the introduction of homelands in the rural areas of the country, as well as the move to create industrial decentralisation, implied that water would play a significant role in the government's plans. 


\section{The Water Act, No. 54 of 1956 and apartheid (1948-1960)}

With the benefit of hindsight, it is evident that the Water Act, No. 54 of 1956 was passed at a critical time in the 20th century history of South Africa. The law was destined to guide the country's water governance for 40 years-specifically in an era when apartheid policies proliferated throughout the country. The apartheid system discriminated against people of colour at a time when human rights, after the acceptance by the United Nations in 1948 of the Universal Declaration of Human Rights, became a principle of appropriate conduct for all societies in an increasingly globalising world.

In South Africa the key reason for the state to shun human rights was the demographic reality that a significant majority of Africans was gaining a commanding presence in the urban areas of South Africa. In its report, the Tomlinson Commission of 1956 provided details on the population statistics for 1951: Europeans 2,6 million; Bantu (i.e.African) 8,5 million; Coloureds 1,1 million; and Asians 367,000, making a total population of 12,6 million people in South Africa. According to the report, in the country's urban areas the population was 'predominantly white', but the picture was rapidly changing. This was evident from the fact that in 1904 only $25 \%$ of the country's people lived in urban areas. By 1951 this tally had risen to 42,6 \% (78 \% Europeans; Bantu $27 \%$, Asians 77,5 \% and Coloureds $64 \%$ ), (Union of South Africa (U of SA), UG61/1955).

The government was determined to ensure that people of European descent (the white minority) maintained control (Posel 2011, p. 323). Evidence of their status implied a comfortable, privileged lifestyle-with access, for example, to reliable water supplies and the prospect of economic development and 'progress' in the greater part of the country (including the 'developed' urban areas) where they lived and worked and enjoyed social and political advantages. However, in terms of government policy it was evident that a different set of values was at play in the rural areas, where people of colour predominated.

Once in power, the National Party government systematically introduced a litany of legislation (U of SA, UG36/1954, p. 8) notable for its overtly discriminatory features. Laws approved by government included, for example: The Prohibition of Mixed Marriages Act of 1949 and the Immorality Act of 1950, both of which prevented personal relations and marriage across the racial divide; the Population Registration Act of 1950, that stipulated that all South Africans had to be classified in terms of race; the Group Areas Act of 1950, which laid down that people had to live in racially demarcated areas of residence; the Bantu Authorities Act of 1951, that permitted government to unilaterally appoint chiefs to do its bidding in the country's rural African reserves; and the Natives Resettlement Act of 1954 , in terms of which the government could override municipal authorities and relocate Africans to separate townships. In the case of Johannesburg, for example, this arrangement led to the removal of more than 58000 Africans from the 'white' municipal area, to what was to become known as Soweto. Furthermore, the Natives (Abolition of Passes and Coordination of Documents) Act of (1952), and the Promotion of Self-government Act of 1959 paved the way for the relocation of people to so-called 'homelands' or what the government chose to call Bantustans. The Transkei, Bophuthatswana, Venda and Ciskei (TBVC states) ultimately even entered into 'international' agreements with South Africa on the transboundary water management in terms of the Helsinki Rules of 1966 (Emmett and Hagg 2001, p. 302; Worden 1994, pp. 95-96; U of SA, UG36/1954, p. 8; RSA, DWA 1986, Sec. 3.1-3.5; RSA, RP109/1979). In a country torn apart by conditions of social and political inequality and discontent, the government's highly acclaimed, sophisticated water sector was bound to come under fire. By the early 1990s the international community was 
highly aware of the apartheid government's historical disregard for the human rights of people of colour - and first among these rights was their inadequate access to water and sanitation. This became one of the most sensitive targets for criticism against the National Party government. ${ }^{4}$ Consequently, one of the first issues to be tackled by the post-1994, democratically elected government, was the provision of water and sanitation to areas that had previously been excluded from services.

\section{The Water Act, 54 of 1956 in the era of emergent apartheid: the rural agricultural setting (1913-1960)}

Attempts by the government, after 1948, to enable Africans to return to the land and farm in the rural areas-preferably in the homelands-were futile. In the 19th century most indigenous people had in fact already been displaced in the interior of the future Union of South Africa (Bundy, 1979) as a result of colonial expansion. The crisis was intensified with the passing of the Land Act of 1913 (Feinberg 2015, pp. 19-36). African labour was in high demand. The system of sharecropping (Africans resident on white owned farms produced crops in collaboration with the property owner and received small portion of the profits) on the Highveld in parts of the Free State and Transvaal, increasingly came under scrutiny by the government and African farmers found themselves in a disadvantaged position. Government wanted Africans to move into what were called Native reserves. Therefore, living conditions on white farms became more precarious. They could either become labour or rent tenants on the land. In the case of rent tenants, they were expected to pay a rent to the property owner. In the case of labour tenancy, it was required of Africans resident on private farms to perform labour (basically free of charge) for the property owner (Troup 1972, pp. 218-219; Ochiltree 1998). As their income from farming declined, African males increasingly entered into the system of wage labour in the urban industrial areas where they worked as migrant labourers to support their families and only periodically returned to their homes (Wickens 1983, p. 61).

From the 1950s the apartheid policy of the government focused strongly on stemming the tide of African migration to the country's cities. For obvious reasons the strategy did not work. Africans faced limited prospects to eke out a decent living in rural areas on the small amount of land available to them (13\% of South Africa's surface area). Taking up employment in the cities, where their poorly-paid labour was sought in the mining and industrial sectors, meant they would not be able to settle down with their families. In terms of the Group Areas Act (of 1950) black South Africans who were employed in the 'white' urban areas were deemed to be 'temporary sojourners' - an arrangement that was later eased somewhat (Posel 2011, p. 329).

The prospect of irrigation - apparently a 'white' technology 'held in high esteem by the African people' (Comaroff and Comaroff 1986) - was designed to act as an innovative strategy for combating African urbanisation. Ironically, previous governments since the early 20th century had done little to promote irrigation in the country's African reserves (U of SA, UG9/1932, pp. 34-35). After World War 2, it seems, there was a renewed government drive to provide water to African reserves. In 1945-1946 the Department of

\footnotetext{
${ }^{4}$ In 1992 the standing committee on water and sanitation (SCOWSAS), was formed to advise the deliberations on South Africa's political transition. The committee levelled strong criticism against the National Party government for its treatment of previously disadvantaged communities in the field of water and sanitation.
} 
Native Affairs, as part of comprehensive plans for the development of the rural areas, spent $£ 126925$ on securing water supplies (U of SA, UG14/1947, p. 10). The funding came from government's mainstream policy framework to give attention to land reclamation in the reserves - a project vigorously supported by the Department of Irrigation (U of SA, UG14/ 1947, pp. 5, 9). The Department of Irrigation supported the policy, but remained committed to a strategy developed by AD Lewis in the 1930s, to construct water storage dams in areas where erosion tended to cause severe damage (U of SA, Department of Irrigation (DOI) 1935; UG15/1936, p. 9). The department was even instrumental in securing water supplies from the Vaalharts scheme to the Taungs native reserve, where 6800 hectares of land came under irrigation and provided 318 garden plots for the benefit of a community of about 2 000 people (U of SA, UG14/1947, p. 6).

From 1948, as part of the government's apartheid strategy, measures followed to improve farming - specifically irrigation farming - in what were to become known as the homelands. Agriculture was seen as being the future mainstay of local food production. To make this policy work, water was vital (Turton et al. 2004, p. 414). The National Party leadership was aware of the benefits of earlier strategies of using irrigation schemes to eliminate white poverty (Tempelhoff 2006; Seekings 2007). However, in respect of the African population's access to water, a scrutiny of the material suggests that an authoritarian approach prevailed (Van Koppen and Schreiner 2014, pp. 543-548). For example, there are few references in the Tomlinson Report to irrigation as one of the low-hanging fruits of poverty eradication. Instead, there was a need for 'firm control' by state officials to ensure that irrigation projects received dedicated attention from participant farmers. Officials, it appeared, had to be strict in the administration and governance of the system (U of SA, UG61/1955, pp. 120-122). Earlier officials of the Department of Irrigation were more optimistic. They were convinced that especially the Transkei region in particular, held considerable promise for farming activity providing that water coming down the steep slopes of the Drakensberg range was managed properly (U of SA, Department of Irrigation (DOI) 1951). There was even a suggestion that hydro-electrical power be generated in the region (U of SA, UG15/1949, pp. 15-16). Based on a report by the Department of Irrigation (U of SA 1951a; U of SA, UG40/1953, p. 3) and in situ investigations, the Tomlinson Commission recommended a number of irrigation projects (Perret 2002, pp. 5-6). A strong argument was that the south-eastern parts of South Africa were most favourably situated for securing water resources (U of SA, UG61/1955, p. 3). In contrast to the western parts of the country, notable for their aridity, the south-eastern areas of the subcontinent clearly favoured rain-fed irrigation schemes.

However, the hardship caused by frequent and persistent drought conditions often had long-lasting consequences for rural African people in the Eastern Cape. For example, no less than a quarter of the livestock perished on farms in the hinterland of East London following a devastating drought in the period from 1945 to 1951 . Impoverished farmers had little or no hope for the future and for many rural people life in the African townships on the outskirts of East London held better prospects than remaining on the land (Lodge 1983, p. 56). In 1954-1955 land survey officials of the Department of Irrigation were seconded to the Department of Native Affairs for the development of irrigation works (U of SA, UG24/1956, p. 9). The department also became heavily involved in borehole drilling in the reserves (U of SA, UG55/1955, p. 15). By 1956-1957 most of the drilling done on contract by the Department of Water Affairs was performed for the Department of Native Affairs in the country's rural areas (U of SA, UG74/1960, p. 10).

The Tomlinson Commission recommended that farmers in the homelands be settled on smallholdings of between 1.3 and 1.6 hectares. It was said to be sufficient to provide for the 
needs of a household (Tapela 2008, p. 182; Perret 2002, p. 5). Earlier experiments suggested that new irrigation farmers had to begin their subsistence agriculture on small pieces of land. Moreover, it was essential for officials of the Department of Native Affairs and the water authorities to collaborate closely on these projects (U of SA, UG15/1949, pp. 7-14). In terms of general crop production, African farming performance in the 1950s remained below par. According to the 1951 census data, white farmers produced on average 11,85 bags of maize per morgen ( 0.85 hectares) while African farmers in the rural areas could only produce 2,25 bags on land of the same size (U of SA, UG61/1955, pp. 85-86). The lower production was said to be largely as a result of physical and economic constraints.

There were also problems for white farmers on certain irrigated lands. Consequently, government found it necessary to relocate Africans from such land. For example, after 1948, the African communities who had traditionally been resident in the fertile valleys of the Drakensberg Mountains between the urban areas of Tzaneen and Duiwelskloof in the Northern Transvaal (today's Limpopo Province) had increased to the extent that they posed a threat to the agricultural activities of local white irrigation farmers. The issue became critical when the authorities realised that the local native reserve areas had not been rigidly demarcated. Native Affairs officials were of the opinion that whites should enjoy preferential treatment because of their 'superior knowledge' of farming with water. Local African farmers, according to the officials, were predominantly active in the field of 'cultivating tomato crops', which were in any case entirely 'subsidised by government'. In turn, presumably in a gesture of magnanimity, the white farmers indicated that they would be prepared to dispose of some of their lands to African communities who had close ties with local traditional leaders (U of SA, UG36/1954, pp. 85-86). When in 1954 construction began on the Ebenezer Dam in the Wolkberg region, where the mountain catchment fed into the Letaba River, white irrigation operations in the Letaba region, between Tzaneen and the Kruger National Park, benefited most. White riparian farming operations flourished in the Lowveld's mild winter climate conditions (Uys, 1996, pp. 51-59). The same could not be said of all homeland areas in the region.

In 1956 the Tomlinson Commission reported that 122 irrigation schemes had been started up in the African areas amounting to a total surface area of 11400 hectares, offering livelihoods for 7538 plot-holders. The northern parts of South Africa's black reserves were said to be most productive, with more than 5000 hectares under irrigation. Then followed the western parts of the country's reserves with 4300 hectares; and Natal with 1500 hectares. The Ciskei and Transkei only managed to respectively put 173 and 103 hectares under irrigation (U of SA, UG61/1955, p. 121). The government planners were optimistic and predicted that eventually an estimated 36,000 families could be settled on 54,000 ha of irrigable land in the homelands (Perret 2002, p. 6). All the early projects were primarily river diversion schemes and the water was conveyed in irrigation canals without linings. After 1950 the state started upgrading existing smallholder canal systems by means of weirs or dams and lining the canals and furrows with concrete. African farming prospects then improved (Van Averbeke et al. 2011, p. 799).

Irrigation farming by Africans was not successful in all parts of the Union. By the mid1950s a total of 28 of 37 new small farming irrigation schemes in South Africa had either collapsed or fallen into disuse. However, in the Transvaal, irrigation seemed to have sparked off enthusiasm among African farmers. In the Nebo district, free labour helped to build 60 earthen dams for irrigation and by 1951-1952 the initiative had contributed 113,000 bags of wheat produced by African farmers. There were also promising reports from the Olifants River in the district (U of SA, UG61/1955, p. 121). In the Letaba district a local black co-operative venture pushed its income up from $£ 9218$ in 1948-1950, to $£ 21$ 
629 in 1951-1952 (U of SA, UG61/1955, p. 121). Further north, in the Soutpansberg region along the Nyelele River, two small farming irrigation schemes made headway, but the farmers' earnings were significantly less than a similar project along the Olifants River (U of SA, UG61/1955, p. 121).

The extent to which the government managed to turn African irrigation technology into a profitable enterprise in the early apartheid era, is difficult to determine. The jury is still out on how successful it might potentially have been. In the new millennium, estimates suggest that in the 'homelands', there were at least 317 irrigation schemes that provided water to 50, 000 ha of arable farming land (Anon 2007, p. 10). After 1994 most schemes became dysfunctional once government withdrew subsidies and support (Tapela 2008, p. 182; Backeberg 2004, p. 362). There appears to be consensus that farming and reclamation initiatives by the authorities since the 1950s in, for example the Transkei, were seldom successful. Moreover, research shows that these initiatives rarely contributed to the conservation of the environment (Hendricks 1989; Crush and Jeeves 1993; De Wet 1990).

\section{The Water Act, 54 of 1956 and Africans in the urban areas: 1900s-1960}

Ever since the early 20th century Africans were attracted to the urban areas of South Africa to search for employment. In many cases African townships established in the segregation era (1905-1948) on the periphery of the so-called white urban areas, were informal settlements. There were attempts at introducing some sanitary measures to allay fears that these settlements were responsible for pandemics such as the bubonic plague in Cape Town's slums in 1902 and in Johannesburg by 1904, as well as the worldwide influenza epidemic of 1918. These measures, defined in terms of Swanson's 'sanitary syndrome' concept, had the additional effect that local authorities resorted to creating so-called 'model townships' in Klipspruit outside Johannesburg and New Brighton near Port Elizabeth (Swanson 1977; Mäki 2008, p. 294; Maylam 1995, p. 24). However, up to the early 1920s authorities dealing with informal housing on the periphery of urban areas only focused on the 'problem' from a public health perspective (Mäki, 2008, Chapts. 4 and 5; Harrison 1992, p. 15). The Native Urban Areas Act of 1923 had the objective of improving the welfare of urban black people by the provision of housing and other social services (Brits 1993, pp. 159-160). In terms of this legislation local authorities now had permission to erect formal housing for people of colour in areas known as 'locations'. However, as a rule local authorities were slow to help demolish the shack dwellings and to sponsor the construction of decent housing for African residents. The period from 1929 to 1948, according to Harrison (1992), marked a peak in the rate of black urbanisation in South Africa. In Johannesburg, for example, the number of black residents increased from 244,000 in 1939 to 400,000 by 1946 (Harrison 1992, p. 15).

In the 1940s government prided itself on what it termed 'good native management'. This implied that employers secured labour from the country's African reserves to work in the mining, industrial and farming sector. There were even initiatives to improve conditions in the reserves by promoting education and training in farming techniques as well as making provision for improved water services and irrigation farming (U of SA, UG14/ 1947, p. 9). However, there was a sting in the tail. Water supplies in the rural areas and the urban slums on the periphery of the large industrial urban centres remained hopelessly inadequate (Gale 1949, p. 395). By this time Africans were an important component of the country's labour sector with black trade unions becoming influential role players (Jeeves 
2004 , p. 5). From the 1940s onwards the government had the responsibility of ensuring that there was sufficient African labour for the urban industries and the agriculturalists in the rural areas (Davies et al. 1976, pp. 19-20; Muller 2011, pp. 46-47). The absence of adequate water supplies, silently played an important role in shaping the fate of many African families in the urban areas.

World War 2 was responsible for a significant disruption of social welfare services in South Africa. The construction of new houses literally came to a standstill. In 1944 a number of sub-tenants living on plots in Orlando left the area with its overcrowded housing and settled on vacant land on the periphery, using rudimentary materials for the construction of squatter shacks. When the municipality of Johannesburg provided more land, local leaders became active in the squatter communities. One example was James Mpanza who headed up the Sofasonke squatter movement (Oakes 1995, p. 356). This early form of African unrest exacerbated urban living conditions with its politically-motivated squatting strategies (U of SA, UG15/1949, p. 19). As the housing crisis worsened the municipality, in collaboration with the government stepped into provide water, sanitation and health services in the townships (U of SA, UG15/1949, p. 19).

In and around other urban areas, living conditions for black people were deteriorating and the police were powerless to act against illegal practices that desperate residents began to instigate. For example, squatters in the Vereeniging area took to securing water from adjoining properties, not always with permission of the owners. Some people even resorted to taking water from a well that was prone to severe pollution (U of SA, UG15/1949, pp. 19-20, 33-34). The trend spread to other urban centres. By 1948 Pretoria was literally 'hemmed in' by squatter villages that had mushroomed on the outskirts of the city. In Cape Town it was estimated that two-thirds of the black population lived within the inner-city in slums and shantytowns on the periphery of the city (Harrison 1992, p. 15). Proper water and sanitation services in these areas were an exception to the rule. And of course population growth compromised water security in a variety of ways.

In the period 1946-1951 the urban areas of the Vaal River Catchment, the major urban population growth region in southern Africa at the time, rose from 2,2 to 2,7 million residents (Badenhorst 1961, p. 97). By 1950, South Africa's Witwatersrand, where most of the country's gold was mined, a population of 2,3 million residents consumed 342 Megalitres (Ml) of water per day (Leslie 1951, p. 18). In the southern parts of the Transvaal the lack of sufficient water had already halted further development by the mid-1950s (U of SA, UG61/1955, p. 109). Furthermore, there were grave concerns that downstream Vaal River water users, such as residents in the new Free State goldfields and the city of Kimberley in the Northern Cape, could experience water shortages (Tempelhoff 2003, pp. 205-206). For geographer Monica Cole it was clear that the development of new townships for Africans placed significant stress on local authorities. They were unable to secure sufficient water supplies, especially in the Witwatersrand conurbation (1957, p. 263). Furthermore, historian, Sheila van der Horst, with good reason, warned of potential 'conflict and competition, sharpened by cultural, colour and linguistic differences' under difficult urban conditions where it was evident that foreign investment in local industries had been insufficient to provide adequate public services such as electricity and water supplies for residents (Van der Horst 1955, pp. 71, 78, 80).

Between 1948 and 1956, 12 African townships were completed in the urban areas of South Africa with a number still under construction (U of SA, UG37/1958, p. 4). However, local authorities were wary of making sufficient services and infrastructure available in the townships, knowing that most of the residents would be too poor to pay for services. This meant that service delivery of potable water, sewerage and waste removal hardly existed 
(or was hopelessly inadequate) and this state of affairs posed a major health hazard (Eloff and Sevenhuysen 2011, pp. 1-25). In 1951 it was estimated there were about 314,000 African families permanently resident in the urban areas with a shortage of about 167,000 dwellings needed to address the shortfall. At the time the cost was calculated to be in the vicinity of about R70 million (Dubb, 1977, p. 86).

In the case of Soweto, the passing of the Bantu Building Workers Act, 27 of 1951 made it possible to train black workers to help with the construction of houses and related buildings in the new township. The legislation only allowed Africans to undertake skilled work in the construction sector if such employment was in designated African areas (O'Malley 1985-1996). At the same time there were financial constraints and a demand for additional funds to cover the cost of water supply and sanitation. Besides the fact that provision had been made in 1953 by local authorities to secure funding from the state, a Bantu Services Levy Fund was established with a view to making money available to pay for essential services inter alia water and sanitation, in the townships (Dubb 1977, p. 86). The levy system required that everyone who employed a black person over the age of 18 years (with the exception of private domestic servants) had to pay 2 shillings and 6 pence per week for each African employee. The monetary contribution were scheduled to finance essential services in the African residential areas (Dubb 1977, p. 86). Initially the levy system was unpopular with employers, but by 1955 , according to the Native Affairs Commission (a body set up by the government to do its bidding) the resistance had dwindled and funds were in fact being used for site-and-service schemes. As many as 49,773 (residential) plots had been provided with services (U of SA, UG54/1956, p. 6; Dubb 1977, p. 86). Government monitored the fund closely and there was strict control on how the funds were spent (U of SA, UG55/1955, p. 11).

The development of new townships for urban African residents created considerable hardship. By 1956 on the Witwatersrand (central Gauteng) as many as 88,015 people who had been classified as illegal squatters had been removed from urban areas to townships. According to the Native Affairs Commission only 3916 families still had to be relocated (U of SA, UG37/1958, p. 5). Meanwhile there were ongoing strikes and boycotts organised by disgruntled urban Africans who were angered by the authorities' determination to eliminate the shantytowns and inner city slums. Many residents were forced to relocate from townships such of Johannesburg's Sophiatown, Pimville, Newclare and the Western Native Township. Similar conditions prevailed in District Six in Cape Town and Cato Manor in Durban (U of SA, RP72/1962, p. 5; P. Harrison 1992, p. 16; Eloff and Sevenhuysen 2011, p. 6). With the decline of the urban slums large new townships, also known as 'locations' in the vernacular, proliferated on the periphery of the South African urban landscape. These included Soweto in Johannesburg; KwaMashu and Umlazi in Durban; and Nyanga and Gugulethu in Cape Town.

In the first decade under the National Party, the government made some headway in providing the housing needs of people in the country's urban areas (Harrison 1992, p. 16). One way in which government wanted to deal with the urban sprawl and the heavy consumption of water in regions that were potentially running dry, was to promote the idea of what it euphemistically called 'decentralisation'. National Party ideologues argued that it was a sound economic strategy to create border industries (on the fringes of African homelands) and thereby reduce the wide divergence in per capita income and employment levels between the four main urban industrial areas of the country and the country's rural areas. At the same time, they maintained, South Africa's land, water and labour resources, could be utilised more effectively (Lumby 1995, p. 81). However, in the longer term the decentralisation strategy did not live up to expectations and it did little to stem the tide of 
African urbanisation. Nevertheless, the strategy remained a priority well into the 1970s (RSA and RP34/1970, pp. 76-82).

\section{The culmination of African resistance to apartheid in the 1950s}

On the surface it appears that water did not play a direct role in African resistance to the apartheid state before 1960s. However, as explained above, water has a deep, but hidden power; it shapes the way people respond to its availability. In the post-apartheid era (after 1994) water and sanitation service delivery problems have been prime drivers of community protest and these demonstrations are becoming increasingly violent (World Wide Fund-South Africa (WWF-SA) 2016, pp. 62-81; Bernstein, 2010). It is quite possible that the lack of reasonable access to water was a driver in urban African protest action against local authorities. While the Water Act of 1956 might have been used to ensure that whites benefited from the available water supplies in both the rural and urban areas, it also contributed to deep-seated dissatisfaction amongst South Africans of colour. They did not have adequate access to water. In the political environment of the 1950s that message would have come across in a pronounced manner. Water stress, like hunger and poverty is a hidden driver of community anger and potential concomitant violent protest (ActionAid 2016, pp. 20-21).

The African response to the government's increasingly repressive policies after 1948 saw the formation of a solidarity movement supported by the African National Congress (ANC), the South African Congress of Trade Unions (SACTU), as well as members of the soon-to-be banned South African Communist Party (SACP). A National Action Council was responsible for drafting the Freedom Charter, scheduled to be made public at a Congress of the People attended by an estimated 2884 delegates from all parts of the country, gathering at Kliptown near Soweto on 26 June 1955 (Oakes 1995, pp. 387-389). Police later broke up the gathering and arrested many of those in the crowd. Ultimately the Freedom Charter, underlining the principle that the country belongs to all its people, became the cornerstone of the African liberation struggle in South Africa and still serves as a compass for the government in framing its democratic revolution (Saul and Bond 2014, pp. 53-55). In December 1956 the first court hearings of the Treason Trial began and 156 activists were charged with plotting to overthrow the government. The trial dragged on interminably and eventually, in 1961, all those charged were acquitted (Oakes 1995, pp. 387-389).

The use of the judiciary to address the discontent of South Africa's black majority acted as a delay mechanism for the apartheid government. Ironically the annual Native Affairs Commission report for 1956 (that was only published in 1958) reported to parliament that:

A spirit of co-operation and good feeling between the various racial groups was noticed everywhere and with that the Commission can only envisage a greater and happier South Africa in which there will be room for all the groups (U of SA, UG37/ 1958, p. 6).

However, subsequent to the protest of 1955 , government rapidly forged ahead in its attempts to transform the country's urban landscape. In its report for the period 1957 to 1960 the Native Affairs Commission claimed that all illegal squatter camps had been removed from the perimeters of the major urban areas in the country. As far as the commission was concerned, it was only in the cities of Durban and Cape Town that work 
was still required to develop residential areas for Africans. Sufficient land, it maintained, had already been set aside for this purpose (U of SA, UG36/1961, p. 6).

Then, in March 1960, the Sharpeville massacre revived the spirit of black protest-with dire consequences for South Africa's international image and by implication, the country's economy. Government insisted it could deal with the situation; it boosted its spending on defence, and forged ahead in providing housing for the African population, like no government had done before. In 1961, MDC de Wet Nel, the Minister of Bantu Administration and Development, announced a five-year plan for Johannesburg. The government would set aside R75 million for the development of more than 81000 houses to be built over an area of $127 \mathrm{~km}^{2}$. Provision had also been made for sufficient water supply in the form of sinking 1531 boreholes (RSA, ARP72/1962, p. 5). But all this proved to be too little, too late. That same year the ANC announced that it would turn to armed struggle to fight for the freedom of the African majority, and Umkhonto we Sizwe (MK) the armed wing of the ANC was formed, led by Nelson Rolihlahla Mandela (Keller, 2013).

\section{Conclusion}

The drive by government, since the 1940s, to promote growth through mining and industrialisation in South Africa positioned the country's water sector to meet the demand for more resources. It was the normal route to follow for states aspiring to make their mark in the international community. In the early 1960s, the development of the Orange River scheme with extensive water storage facilities, even capable of generating hydropower, was clearly a South Africa's response to the neighbouring Federation of Rhodesia and Nyasaland where in 1958 the government completed construction work on the formidable Kariba Dam project - at the time the largest artificial lake in the world, with substantial capacity to generate hydroelectric power (Cole, 1960).

At a time in the late 1950s when Africa entered the phase of progressive decolonisation, officials in South Africa's Department of Water Affairs were planning the Orange River project (Emmett and Hagg 2001, p. 300). It became a testimony to the status and ability of South African civil engineering, supported by international consultants. The initiative inspired a sense of national pride, primarily among the privileged white population of the country.

Annual reports by the Department of Irrigation/Water Affairs for the period 1948-1960 suggest that the department kept a firm focus on planning within the paradigm of rapid development and economic growth, a path followed by Western democratic economies in the 1950s. The major difference in the case of South Africa was that externalities from the year 1948 (when the NP came to power) influenced and shaped national development. For example, the movement towards the postcolonial phase of African development saw South Africa increasingly swimming against the proverbial tide of trends in the rest of Africa. Despite the country's growing isolation the government was shored up by the support of the majority of eligible (white) voters. Government became progressively harsher in enforcing its policy of racial segregation. It was determined to preserve white minority rule, a salient feature of the apartheid policy. In 1955, a year before the passing of the Water Act of 1956, the African opposition and its supporters, made a profound statement in the Freedom Charter. They demanded that all South Africans should share the country's wealth in terms of its available resources. This surely included sharing the country's water resources. But that goal would only effectively be realised in the 1990s. 
What is evident in a study of the period 1948-1960 is that the officials of the Department of Water Affairs focused increasingly on water supply across a broad and comprehensive front. In time to come they became very adept at developing advanced water supply schemes. By the 1960s the African homelands received more attention. In the 1970s a Water Commission report advised government to cooperate more closely with the Department of Water Affairs in planning the homelands and the proposed decentralisation policy of 'border industries'. It was an integral part of the homeland policy (RSA and RP34/1970, pp. 15-16). An inter-departmental committee subsequently spent five years working on a comprehensive scheme to address the issue of water-sharing with the homelands (RSA, RP109/1979). The hydrological focus was on securing water supplies, ensuring sound water quality and being supportive of economic development over a comprehensive, but ambiguous economic front. In technical terms many of the ideas had substantial value, especially in terms of local and regional water governance in South Africa's water catchment areas. However, its implementation was flawed as a result of a racially tinted approach to governance.

Politically, the Department of Water Affairs was not an active role player in securing water supplies for urban townships. For the most part that responsibility was transferred to local authorities. One consequence was the notably inferior water and sanitation services in the African townships from the 1960s onwards. This issue was only addressed in some measure after the Soweto uprising of 1976, when additional steps were taken at local and regional government level for authorities to improve water supply and sanitation in the African townships of the urban areas (Tempelhoff 2003, pp. 332-340).

Acknowledgements: The author is grateful for valuable comments and advice from colleagues and associates, Bridget Bushnell-Theron, Martin Ginster and Germarie Viljoen, as well as two anonymous reviewers. Their critical views on the weft and warp, of the historical weaving process has been of immense value. A sincere thanks to them. This research forms part of a project entitled the Cultural Dynamics of Water in South Africa (1910-1960) funded by South Africa's National Research Foundation (NRF): Project CSUR13091742560. The NRF is by no means responsible for opinions expressed by the author.

Open Access This article is distributed under the terms of the Creative Commons Attribution 4.0 International License (http://creativecommons.org/licenses/by/4.0/), which permits unrestricted use, distribution, and reproduction in any medium, provided you give appropriate credit to the original author(s) and the source, provide a link to the Creative Commons license, and indicate if changes were made.

\section{References}

ActionAid (2016) Running on empty: what business, government and citizens must do to confront South Africa's water crisis. In: Water Interrupted Campaign, 64. s.l. ActionAid, South Africa

Adler RA, Claassen M, Godfrey L, Turton AR (2007) Water, mining, and waste: an historical and economic perspective on conflict management in South Africa. Econ Peace Secur J 2(22):33-41

Anon (1942) South Africa's Social and Economic Planning Council: general Smuts's plans for a better and greater Southern Africa. J R Afr Soci 41(165):231-233

Anon (2007) Water Research Commission initiated project: advertorial. SA Irrigation 29(5):10

Anon (c. 1987) A historical overview of the Department of Water Affairs. In Department of Water Affairs (DWA), Water 75 (Erudita Publications (Pty) Ltd., Johannesburg

Backeberg GR (2004) Research management of water economics in agriculture — an open agenda. Agrekon 43(3):281-290

Badenhorst LT (1961) A demographic profile of the Vaal catchment area. In: Vaal River Catchment Association (VRCA), Vaal: Problems of a river's future. Papers read at a symposium on the future of the Vaal River, Johannesburg, 30 September-1 October, 1961. Supreme Printers, Johannesburg, pp 91-122 
Basson JL (1980) J.G. Strijdom: Sy politieke loopbaan van, 1929 tot 1948. Wonderboom-uitgewers, Pretoria Beinart W (1984) Soil erosion, conservation and ideas about development: a Southern African exploration, 1900-1960. J South Afr Stud 11(1):52-83

Bernstein A (ed) (2010) Water: a looming crisis? In CDE Round Table 14. Business Leadership South Africa and the Centre for Development and Enterprise, Johannesburg

Brits JP (1993) Political development and the depression of 1929-1934. In: Liebenberg BJ, Spies SB (eds) South Africa in the twentieth century. JL van Schaik, Pretoria, pp 224-266

Bundy C (1979) The rise and fall of the South African peasantry. University of California Press, Berkeley

Butler J, Rotberg RI, Adams J (1978) The black homelands of South Africa: the political and economic development of Bophuthatswana and KwaZulu. University of California Press, Berkeley

Christopher AJ (2001) The atlas of changing South Africa, 2nd edn. Routledge, London

Cole MM (1957) The Witwatersrand conurbation: a watershed mining and industrial region. Trans Pap Inst Br Geogr 23:249-265

Cole MM (1960) The Kariba project. Geography 45(1/2):98-105

Comaroff J, Comaroff J (1986) Christianity and colonialism in South Africa. Am Ethnol 13(3):1-22

Conley A (1988) The Department of Water Affairs: a tradition of engineering excellence. Civ Eng 30(5):221-347

Crush J, Jeeves A (1993) Transitions in the South African countryside. Can J Afr Stud 27(3):351-360

Davies R, Kaplan D, Morris M O'Meara, D (1976) Class struggle and the periodization of the state in South Africa. Afr Polit Econ, 7: 4-30 (Special issue on South Africa)

De Wet C (1990) The socio-ecological impact of development schemes in the 'homelands' of South Africa. South Afr J Sci 86:7-10

Department of Water Affairs and Forestry (DWAF) (2006) A history of the first decade of water service delivery in South Africa 1994-2004: meeting the millennium Development Goals. Department of Water Affairs and Forestry, Pretoria

Dubb A (1977) The development of an African township. South Afr J Sci 73(3):86-88

Eloff S, Sevenhuysen K (2011) Urban black living and working conditions in Johannesburg, depicted by township art (1940s-1970s). SA Tydskrif vir Kultuurgeskiedenis 25(1):1-25

Emmett T, Hagg G (2001) The politics of water management: the case of the Orange River Development Project. In: Khosa MM (ed) Empowerment through economic transformation. African Millennium Press, Durban, pp 299-328

Fagan B (2011) Elixir: a human history of water. Bloomsbury, London

Fair TJD, Webb HW (1954) The South-Eastern Transvaal Lowveld: a Survey of the Resources and Development of the Southern Lowveld Region of the Eastern Transvaal. Lowveld Regional Development Association, Barberton

Feinberg HM (2015) Our land, our life, our future: black South African challenges to territotial segregation, 1913-1948. De Bruyn J, Viljoen R (eds) Hidden Histories Series, Unisa Press, Pretoria

Fishman C (2011) The big thirst: the secret life and turbulent future of water. Free Press, New York

Freund B (1910) South Africa: the union years. In: Ross R, Mager AK, Nasson B (eds) The Cambridge history of South Africa 1885-1994, vol 2. Cambridge University Press, Cambridge, pp 211-253

Gale GW (1949) Health services. In: Hellmann E (ed) Handbook on race relations in South Africa. South African Institute of Race Relations. Oxford University Press, Cape Town, pp 387-412

Giliomee H (2003) The Afrikaners: biography of a people. Tafelberg, Cape Town

Gunthorp M (1973) The Vaal-Harts irrigation scheme. In The Civil Engineer 44-47

Hall CG (1939) The origin and development of water rights in South Africa. Oxford University Press, Oxford

Hall CG (1947) The origin and development of water rights in South Africa, 2nd edn. Oxford University Press, Oxford

Hall CG, Burger AP (1974) Hall on Water Rights in South Africa, 4th edn. Juta \& Co. Limited, Cape Town

Harrison P (1992) Urbanisations: the policies and politics of informal settlement in South Africa: a historical perspective. Afr Insight 22(1):14-22

Hay A (2013) Obituary: eric John Hall. Civ Eng 12(9):65-67

Hellmann E (ed) (1949) Handbook on race relations in South Africa. South African Institute of Race Relations. Oxford University Press, Cape Town

Hendricks FT (1989) Loose planning and rapid resettlement: the politics of conservation and control in Transkei, South Africa, 1950-1970. In Journal of Southern African Studies 15(2), Special issue on the politics of conservation in southern Africa: 306-325

Horak D (1978) An interview with Dr Daniel Kokot. Civ Eng S Afr 20(12):330

Huchzermeyer M (2003) A legacy of control? The capital subsidy for housing, and informal settlement intervention in South Africa. Int J Urban Reg Res 27(3):591-612 
Jeeves A (2004) South Africa in the 1940s: post-war reconstruction and the onset of apartheid. S Afr Historical J 50:1-11

Kanthack FE (1924) Irrigation in the Union: a discussion of policy in relation to the conservation of water. J S Afr Inst Eng 174-181

Keller B (2013) Nelson Mandela, South Africa's liberator as prisoner and president, dies at 95. New York Times, 5:107-121

Krüger DW, Beyers CJ (eds) (1977) Suid-Afrikaanse Biografiese Woordeboek, vol III. Tafelberg Uitgewers, Kaapstad

Lahiff E (1997) Land, water and local governance in South Africa: a case study of the Mutale River Valley. In: Rural resources rural livelihoods working papers, No. 7. Economic and Social Research Council, United Kingdom

Le Roux C (2000) The question of housing for Africans in Mangaung at Bloemfontein 1945-1964. Historia 45(2):465-485

Legassick M (1974) Legislation, ideology and economy in post-1948 South Africa. J South Afr Stud 1(1):5-35

Leslie JP (1951) The supply of water within the area served by the Rand Water Board and its relation to social and economic development with special reference to the Vaal River. Civ Eng 1(1):17-27

Liebenberg BJ, Spies SB (eds) (1993) South Africa in the twentieth century. JL van Schaik, Pretoria

Lodge T (1983) Black politics in South Africa since 1945. Longman, London

Lumby A (1995) Industrial history in South Africa: past trends and future needs. S Afr J Econ History 10(1):74-88

Mabin A (1992) Comprehensive segregation: the origins of the Group Areas Act and its planning apparatuses. J South Afr Stud 18(2):405-429

Mabin A, Smit D (1997) Reconstructing South Africa's cities? The making of urban planning 1900-2000. Plan Perspect 12(2):193-223

Makanjee V (1987) Lebowa's dungeons and dragons. Indic SA 4(4):79-82

Mäki H (2008) Water, sanitation and health: the development of the environmental services in four South African cities, 1840-1920. Juvenes Print, Tampere

Marx C, Charlton S (2003) The case of Durban, South Africa. In UN-Habitat, The challenge of slums: global report on human settlements (2003), United Nations Human Settlements Programme. Earthscan Publications Ltd, London

Maylam P. (1995) Explaining the Apartheid city: 20 years of South African urban historiography. J S Afr Stud: $19-38$

Meintjes BJ (1975) Sasol 1950-1975. Tafelberg, Kaapstad

Mountain ED (1955) The Uitenhage artesian Basin. S Afr J Sci 52(3):66-72

Muller CH (2011) Coercive agrarian work in South Africa, 1948-1960: Farm labour a scandal?. MHCS University of Pretoria, Pretoria

Murray JM (ed.) (1952) The Union Statutes and annotated reprint 1910-1947, Volume 12, Butterworth \& Co. (Africa) Ltd, Durban

Nienaber PJ (1977). Van Reenen, Reenen Jacob. In: DW Krüger en CJ Beyers (eds), Suid-Afrikaanse Biografiese Woordeboek, III. Tafelberg Uitgewers, vir die RGN, Kaapstad, 1977, p. 837

O' Malley P. (1985-1996) O’Malley Archive: The heart of Hope (1985-1996) Native building workers Act, 27 of 1951. Nelson Mandela Centre of memory at http://bit.ly/2c5XiYu Accessed 28 Aug 2016

Oakes D (ed.) (1995) Reader's Digest illustrated history of South Africa: The real story. Expanded $3^{\text {rd }}$ ed, Reader's Digest Association, Cape Town: 352-380

Ochiltree ID (1998) 'A Just and Self-Respecting System'?: black independence, sharecropping, and paternalistic relations in the American South and South Africa. Agric Hist 72(2):352-380

Olivier G (2011) The location. In: Grundlingh A, Huigen S (eds) Reshaping remembrance: Critical essays on Afrikaans places of memory. Rozenberg Publishers, Amsterdam, pp 15-22

Perkins P, Fedderke J, Luiz J (2005) An analysis of economic infrastructure investment in South Africa. In Centre for Social Science Research, Working Paper No. 102, University of Cape Town, Cape Town

Perret S (2002) Water policies and smallholding irrigation schemes in South Africa: A history and new institutional challenges. In Department of Agricultural Economics, Extension and Rural Development, Working Paper 2002-19, University of Pretoria, Pretoria

Pfister C (2010) The '1950s syndrome' and the transition from a slow-going to a rapid loss of global sustainability. In: Uekoetter F (ed) The turning points of environmental history. University of Pittsburgh Press, Pittsburgh, pp 1250-1597

Posel D (1999) Whiteness and power in the South African civil service: paradoxes of the apartheid state. J South Afri Stud 25(1):99-119 
Posel D (2011) The Apartheid project, 1948-1970. In R Ross, AK Mager, B Nasson (eds) The Cambridge history of South Africa 1885-1994, Vol. 2 Cambridge University Press, Cambridge, pp 318-368

Redlinghuis AC (1991) Geforseerde residensiële hervestiging, Bellville, 1950-1960. In Kronos 18:29-66

Republic of South Africa (RSA) 1997, Water Services Act, No. 108. In Government Gazette, 390(18522), 12.19: $1-70$

Republic of South Africa (RSA) Department of Water Affairs (DWA) (1986) Management of the water resources of the Republic of South Africa. CTP Printer for the Government Printers, Pretoria

RSA (1998) National Water Act, No. 36. In Republic of South Africa Government Gazette, 398(19182), 08.26: $1-152$

RSA, RP34/1970. Report of the commission of enquiry into water matters. Government Printer, Pretoria

RSA, RP72/1962, Report of the Bantu Affairs Commission for the year 1 January 1961, to 31 December 1961, Government Printer, Pretoria

RSARP109/1979, Report of the interdepartmental committee concerning the division of water between the black states, the remainder of the Republic of South Africa and the republics of Bophuthatswana and Transkei (Report completed 12 December 1978, Pretoria)

Saul JS, Bond P (2014) South Africa: The present as history from Mrs Ples to Mandela and Marikana. James Currey, Woodbridge

Scholtz, JJJ (1987) Sauer, Paul Olivier. In CJ Beyers and JL Basson (eds), Suid-Afrikaanse Biografiese Woordeboek, Volume V (RGN, Pretoria: pp. 716-720

Seekings J (2007) 'Not a single white person should be allowed to go under': swartgevaar and the Origins of South Africa's Welfare State, 1924-1929. Journal of African History 48(3):375-394

Seekings J (2016) State-building, market regulation and citizenship in South Africa. European Journal of Social Theory 19(2):191-209

Singer, M (2011) Facing coal: changing conceptions of South African coal-based pollution, with special reference to the Witbank Coalfield, 1906-1978. African Studies Centre, African Studies Collection, Vol. 31, Ipskamp Drukkers, Enschede

Solomon, S (2010) Water: the epic struggle for wealth, power and civilization. Harper-Collins, eBook

South African Water History Archival Repository (SAWHAR) Will Alexander Collection (WAC), 1955. Notes on other schemes, JL Stallybras, "O.F.S. Goldfields water supply scheme: survey of factors affecting provision to be made in the duplication of the ring-main from Koppie Alleen," 09.16, pp 1-8

Suzman H (1948) 'n Samevatting van die verslag van die Fagankommissie van ondersoek na die Naturellewette. Suid-Afrikaanse Instituut vir Rasseverhoudinge, Johannesburg

Swanson MW (1977) The sanitation syndrome: bubonic plague and urban native policy in the Cape Colony, 1900-1909. The Journal of African History 18(3):387-410

Tapela BN (2008) Livelihoods in the wake of agricultural commercialisation in South Africa's poverty nodes: insights from small-scale irrigation schemes in Limpopo Province. Development Southern Africa 25(2):181-198

Tempelhoff JWN (2003) The substance of ubiquity: Rand Water 1903-2003. Kleio Publishers, Vanderbijlpark

Tempelhoff JWN (2006) Omgewingslagoffers of armblankes? Water en welvaartskepping in die era van Hertzog (1924-1939). Suid-Afrikaanse Akademie vir Wetenskap en Kuns, Pretoria

Tewari DD (2009) A detailed analysis of evolution of water rights in South Africa: an account of three and a half centuries from 1652 AD to present. Water SA 35(5):693-710

Thompson H (2006) Water law: A practical approach to resource management and the provision of services. Juta, Cape Town

Triebel C, Van Niekerk PH (1994) The water supply systems in South Africa. In: Jordaan JM (ed) Large dams and water systems in South Africa. South African National Commission on Large Dams, Pretoria, pp 30-43

Troup F (1972) South Africa: An historical introduction. Eyre Methuen, London

Turton AR Meissner R Mampane PM and Seremo O (2004) A hydropolitical history of South Africa's international river basins. Water Research Commission. Report No. 1220/1/04, Pretoria

Union of South Africa (U of SA) 1926. Irrigation Commission Act, No. 22 of 1926, in JM Murray (ed.), (1952) The Union Statutes and annotated reprint 1910-1947, Volume 12. Butterworth \& Co. (Africa) Ltd, Durban, pp. 425-432

Union of South Africa (U of SA) 1947. Natural Resources Development Act, No. 15. In Murray, JM, Hoal, W.C., Pollak, W and Gross, GN (editorial board) (1952). The Union Statutes 1910-1947, Classified and Annotated Reprint, 1st ed., 12 vols., vol. 12, Butterworth and Co. (Africa) Ltd, Durban, pp. 841-860

Union of South Africa (U of SA) 1951. Bantu Authorities Act, No. 68 of 1951

Union of South Africa (U of SA) 1951a. Native Building Workers' Act, No. 27, 1951

Union of South Africa (U of SA) 1952. Native Laws Amendment Act, No. 54 of 1952 
Union of South Africa (U of SA) 1952a. Native Services Levy Act, No. 64 of 1952

Union of South Africa (U of SA) 1952b. Native Abolition of Passes and Co-ordination of Documents Act, No. 67 of 1952

Union of South Africa (U of SA) 1956. Water Act, No. 54, in U. of SA, Statutes of the Union of South Africa 1956. Part II Nos. 47-73. Cape Times Ltd, under supervision of the Government Printer, Parow, pp. 1046-1305

Union of South Africa (U of SA), Department of Irrigation (DOI) (1935) Small dams across streams, Professional Paper, No. 8.Government Printer, Pretoria

Union of South Africa (U of SA), Department of Irrigation (DOI) (1951) The water resources and use of water in the Transkei, Great Kei and Amatola main drainage regions, including the native territories of the Transkei and Ciskei. Department of Irrigation, Pretoria

Union of South Africa (U of SA) Mackenzie LA (1947) Memorandum on the water resources of the Union of South Africa: A memorandum for presentation by the Director of irrigation to the inaugural meeting of the Natural Resources Development Council December 1947 (Typewritten manuscript, Department of Irrigation, Pretoria)

Union of South Africa (U of SA), Murray JM, Hoal WC, Pollak W, Gross GN (editorial board) (1952) The Union Statutes 1910-1947, Classified and Annotated Reprint. 1st ed. Vol. 12. Butterworth and Co. (Africa) Ltd, Durban

Union of South Africa (U of SA), UG14/1947, Report of the Native Affairs Commission for the year 1945-46. Government Printer, Cape Town

Union of South Africa (U of SA), UG15/1949, Report of the Native Affairs Commission for the period 1 April, 1946, to 31 December 1947. Cape Times Limited, Cape Town

Union of South Africa (U of SA), UG24/1956, Report of the Director of Irrigation for the period 1 April to 31 March 1955. Union of South Africa, Government Printer

Union of South Africa (U of SA), UG29/1925, Eersteverslag van die finansiële besproeiingskommissie. Cape Times Bpk, Gowerment Drukkers

Union of South Africa (U of SA), UG36/1954, Report of the Native Affairs Commission for the period 1 January 1948, to 31 December 1952. Government Printer, Pretoria

Union of South Africa (U of SA), UG36/1961, Report of the Bantu Affairs Commission for the period 1January, 1957 to 31 December 1960. Government Printer, Pretoria

Union of South Africa (U of SA), UG37/1958, Report of the Native Affairs Commission for the period 1 January 1956, to 31 December 1956. Government Printer, Pretoria

Union of South Africa (U of SA), UG4/1938, Annual report of the Irrigation Commission for the period year ending 31 March 1937.Government Printer, Pretoria

Union of South Africa (U of SA), UG40/1953. Natural Resources Council: The Vaal River: report on the water supplies of the Vaal River in relation to its future development. Government Printer, Pretoria

Union of South Africa (U of SA), UG54/1956, Report of the Native Affairs Commission for the period 1 January 1955, to 31 December 195 . Government Printer, Pretoria

Union of South Africa (U of SA), UG55/1947, Verslag van die Direkteur van Besproeiing vir die tydperk 1 April 1940 tot 31 Maart 1946. Staatsdrukker, Pretoria

Union of South Africa (U of SA), UG55/1955, Report of the Native Affairs Commission for the period 1 January 1954, to 31 December 1954. Government Printer, Pretoria

Union of South Africa (U of SA), UG55/1947, Report of the director of Irrigation for the period 1 April (1940) to 31 March 1946. Government Printer, Pretoria

Union of South Africa (U of SA), UG61/1955, Summary of the report of the Tomlinson Commission for the socio-economic development of the Bantu areas within the Union of South Africa. Government Printer, Pretoria

Union of South Africa (U of SA), UG65/1949, Report of the Director of Irrigation for the period 1 April 1947 to 31 March 1948. Government Printer, Pretoria

Union of South Africa (U of SA), UG74/1960, Report of the Director of Water Affairs for the period 1 April 1956 to 31 March 1957. Government Printer, Pretoria

Union of South Africa (U of SA), UG76/1960, Report of the Director of Water Affairs for the period 1April, 1958 to 31 March, 1959. Government Printer, Pretoria

Union of South Africa (U of SA), UG9/1932, Jaarverslag van die besproeiingskommissievir die jaar eindigende 31 Maart 1931. Staatsdrukker, Pretoria

Union of South Africa (U of SA), Water Act, No. 54 of 1956, Assented to on 12 June 1956 and commenced on 13 July 1956, in Statutes of the Republic of South Africa: Water, pp. 1201-1399. In Food and Agricultural Organisation of the United Nations (FAO), Legal Office: FAOLEX at http://goo.g1/PzIISQ Accessed 14 June 2015 
UG15/1936, Annual report of the director of irrigation for the period 1st April, 1934, to 31st March, 1935 Government Printer, Pretoria, p 9.

Union of South Africa (U of SA) (1912). Irrigation and Conservation of Water Act, 8. In JM Murray (ed.) (1952) The Union Statutes and annotated reprint, 1910-1947, Volume 12. Butterworth \& Co. (Africa) Ltd, Durban, pp. 283-482

Uys M (1996). A structural analysis of the water allocation mechanism of the Water Act, No. 54 of 1956 in the light of the requirements of competing water user sectors, Volume 1, Water Research Commission, WRC Report 406/1/96, Pretoria

Van Averbeke, W Denison, J Mnkeni, PNS (2011) Smallholder irrigation schemes in South Africa: a review of knowledge generated by the Water Research Commission. In: Water SA, 37(5) WRC 40-year celebration special edition: 797-808

Van der Horst ST (1955) The Union of South Africa: economic problems in a multiracial situation. Ann Am Acad Political Soc Sci 298:71-83

Van Koppen B, Schreiner B (2014) Moving beyond integrated water resource management: development of water management in South Africa. Int J Water Resour Dev 30(3):543-558

Van Rensburg APJ (1977) Strijdom, Johannes Gerhardus. In: DW Krügeren CJ Beyers (eds), Suid-Afrikaanse Biografiese woordeboek, Volume III. Tafelberg Uitgewers, Kaapstad, pp 785-793

Van Vuuren L (2009) What's in a name? Looking back at the start of public water governance. Water Wheel 8(4):38-41

Van Vuuren L (2012) In the footsteps of giants-exploring the history of South Africa's large dams. Water Research Commission Report SP 11/12, Pretoria

Viljoen PS (1986) Development initiatives of the KwaZuluNatal Planning Council in the informal black settlements around Durban. Civ Eng 28(6):211-217

Visser D, Jacobs A, Smit A (2008) Water for Saldanha: war as an agent of change. Historia 53(1):130-161

Wall K (2011) A century of infrastructure service delivery: commentary. S Afr J Sci 107(11-12):1-3

Wickens PL (1983) Agriculture. In: Coleman FL (ed) Economic history of South Africa. HAUM, Pretoria, pp 37-88

Wolpe H (1990) Race class and the apartheid state. Africa World Press Inc, Trenton, pp 60-74

Worden N (1994) The making of modern South Africa: conquest, segregation and apartheid. Blackwell, Oxford

World Wide Fund-South Africa (WWF-SA) (2016) Water facts and futures: Rethinking South Africa's water future. WWF, Cape Town 